\title{
Towards Sustainability in Higher-Education Institutions: Analysis of Contributing Factors and Appropriate Strategies
}

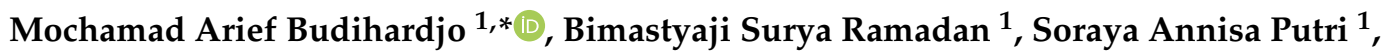 \\ Indah Fajarini Sri Wahyuningrum ${ }^{2}$ and Fadel Iqbal Muhammad ${ }^{3}$ \\ 1 Department of Environmental Engineering, Universitas Diponegoro, Semarang 50275, Indonesia; \\ bimastyaji@live.undip.ac.id (B.S.R.); sorayaannisap@alumni.undip.ac.id (S.A.P.) \\ 2 Department of Economics, Universitas Negeri Semarang, Semarang 50229, Indonesia; \\ i.fajarini@mail.unnes.ac.id \\ 3 Deparment of Environmental Sciences, Wageningen University and Research, \\ 6700 AE Wageningen, The Netherlands; fadel.muhammad@wur.nl \\ * Correspondence: ariefbudihardjo@lecturer.undip.ac.id
}

\section{check for} updates

Citation: Budihardjo, M.A.; Ramadan, B.S.; Putri, S.A.; Wahyuningrum, I.F.S.; Muhammad, F.I. Towards Sustainability in Higher-Education Institutions: Analysis of Contributing Factors and Appropriate Strategies. Sustainability 2021, 13, 6562. https://doi.org/ $10.3390 /$ su13126562

Academic Editor: JESÚS NICASIO GARCÍA SÁNCHEZ

Received: 28 April 2021

Accepted: 4 June 2021

Published: 9 June 2021

Publisher's Note: MDPI stays neutral with regard to jurisdictional claims in published maps and institutional affiliations.

Copyright: (c) 2021 by the authors. Licensee MDPI, Basel, Switzerland. This article is an open access article distributed under the terms and conditions of the Creative Commons Attribution (CC BY) license (https:/ / creativecommons.org/licenses/by/ $4.0 /)$.

\begin{abstract}
To depict detailed sustainability efforts that have been implemented in campus environments, research was conducted at the Universitas Diponegoro (UNDIP), a leading green campus in Indonesia. The aim of the current study was to explore how sustainable development has been conducted by UNDIP and to identify factors that may indicate the existence of sustainability activity in higher-education institutions (HEIs). Factors affecting sustainability implementation in HEIs were derived using bibliometric analysis. Information on the implemented strategies to maintain the sustainability of HEIs was obtained via a closed questionnaire to 40 relevant experts, and analyzed using strengths, weaknesses, opportunities, and threats (SWOT) analysis, and quantitative strategic-planning matrix (QSPM) analysis. Institutional commitment to sustainability and guidance to implement sustainability in HEIs were found to have the highest scores with regard to internal and external factors. The respondents selected more aggressive strategies for the enhancement of sustainability implementation at UNDIP. Fostering external collaboration should be a priority for UNDIP since this can provide mutual benefits and significant improvement towards achieving Sustainable Development Goals (SDGs). The current study provides a robust self-assessment method for selecting appropriate strategies to maintain HEI sustainability.
\end{abstract}

Keywords: higher-education institution; sustainability; SWOT-QSPM analysis; PDCA cycle; SDGs

\section{Introduction}

Higher-education institutions (HEIs) are seen as crucial for individuals [1]. Their principal function is to improve the quality of human resources, which a highly competitive job market serves to increasingly drive. However, meeting educational qualification criteria is not the only benchmark of a successful higher education system [2]. In addition to students accomplishing their study objectives in their respective subjects, they must also gain an understanding of important social issues around them [3]. Sustainable development is the utilization of natural resources while still paying attention to environmental aspects [4]. On the grounds of intangibility, sustainable development is seen as an integrated concept comprising four pillars: environmental, economic, social, and cultural consideration, where the cultural aspect finds common ground in the area of ethical values. A growing concern in several areas is that the three-pillar model of sustainability, consisting of environmental, economic, and social dimensions, needs to be adjusted as demanded by environmental, economic, social, and cultural challenges [5]. A campus requires an environment that provides academic support and comfort through making the space safe, healthy, and clean [6].

The top global HEIs have implemented environmental-management systems (EMSs) and participated in campus sustainability to combat climate change by reducing air pol- 
lution and emissions from transportation, and waste from campus facilities, increasing research-and-development (R\&D) potential towards green campus initiatives $[7,8]$. The University of Florence, for example, has implemented a sustainable education, research, and waste-management initiative [9]. The Universitat Politècnica de València has implemented an EMS as a sustainability tool on campus [10]. Additionally, the University of Jordan implemented a recycling program to improve sustainability on campus [11]. To measure achievement around sustainability for HEIs, several institutions conduct ranking programs of green marketing tools related to campus sustainability aspects [12]. Among these aspects are environmental and policy factors, including the integration of environmental issues, environmental management, environmental performance, and their impact on a campus [13]. A globally acknowledged program among universities is UI GreenMetric World University Ranking, which aims to create a global ranking system for HEIs to enforce sustainability behavior on campus [14]. This is the first attempt to be predominantly managed using an online and open system. This metric can promote HEIs and central governments to support green campus initiatives and environmental efforts in their activities [15].

Universitas Diponegoro (UNDIP) is striving to become an excellent research university and world-class university (WCU). UNDIP has been participating in the UI GreenMetric ranking since 2014 towards developing green university programs as a tool for achieving the Sustainable Development Goals (SDGs) [16]. Like many other WCUs, UNDIP has continued to develop its educational system while also paying more attention to environmental issues. Some environmental problems that are of primary concern to these HEIs are renewable energy, climate change, integrated waste management, the conservation of water resources, and green infrastructure [17]. However, there are multiple obstacles to realizing a green campus, and these often worsen the effectiveness of SDG implementation at each HEI. Therefore, a case study of UNDIP could provide valuable insight, as UNDIP improved its sustainability ranking from being the sixth to being the second greenest university in Indonesia from 2017 to 2020 based on UI GreenMetric.

Sustainability efforts in HEIs can be conducted via an integrative model with various dimensions, including teaching and learning activities, research, campus operation, outreach, and administration [18]. The purpose of this study is to provide a sustainability model implemented by UNDIP that affects sustainability performance and strategic development towards maintaining and implementing sustainability at UNDIP. In this context, other HEIs can apply the same or even better improvements in the area of sustainability. Bibliometric analyses from recent scientific publications were used to construct factors that influence HEI sustainability performance. Strengths, weaknesses, opportunities, and threats (SWOT) analysis and a quantitative strategic-planning matrix (QSPM) were used in this process. This paper provides insight into how sustainability is managed, achieved, and maintained at HEIs, taking UNDIP as an example.

\section{Materials and Methods}

\subsection{Systematic Review}

Systematic reviews can be divided into three types. Domain-based reviews (structured reviews, bibliometric frameworks, hybrid structured reviews-bibliometric studies, and studies aimed at theory development), theory-based reviews, and review-based methods. Structured reviews assist researchers in finding research loopholes in theories and methods, and construction is based on compiled information [19]. To define and search what the factors that influence sustainability in HEIs are, literature reviews that incorporate PRISMA process as qualitative systematic review and science mapping as quantitative approach were conducted following the methodology of Cavalieri et al. [20]. Science mapping was employed to assess the sustainability factors of HEIs that are globally studied by many researchers. The PRISMA 2020 [21] guidance was used for the systematic review. This step consisted of identification, screening, eligibility, and inclusion phases before science mapping and qualitative content analysis were conducted. The first step of the systematic 
review (identification phase), which was drawn from paper selection and delimitation, was conducted to find appropriate publications and their metadata that influence sustainability in HEIs [22]. The Scopus database (accessed on 27 February 2021) was used for extracting a large amount of metadata and citation information [23]. Three keywords were used for the preliminary screening of relevant articles. The term "higher-education institution" (57,744 documents) was used, and a search was continued with results for the words "sustainability" (4411 documents) and "factor" (1938 documents). Some studies were excluded from the pool of studies because they had ambiguous methods, insufficient statistics, and lacked quality. In the screening phase, the articles were limited to research articles, review articles, and conference proceedings written in English (1686 documents) over 15 years, from 2007 to 2021 . These consecutive years correspond to the implementation of sustainable development in HEIs and cover the UI GreenMetric acquisition since 2010. Six journals with the highest number of publications in the area of HEI sustainability implementation were selected. These were Sustainability (134 documents), International Journal of Sustainability in Higher Education (98 documents), Journal of Cleaner Production (95 documents), International Journal of Educational Management (17 documents), Studies in Higher Education (12 documents), and International Journal of Innovation Creativity and Change (11 documents). In the eligibility phase, 215 documents were found. The authors observed and selected papers that were eligible according to the following criteria: (1) publication focus on the case-study approach; (2) the studies emphasized sustainability design, promotion, and implementation in HEIs; and (3) the studies explored the impact of sustainability benchmarking among universities. In the inclusion phase, there were 181 papers that were further analyzed. The authors excluded papers that did not emphasize the relationship between factors and sustainability achievements of HEIs. All abstracts and title metadata were then extracted for bibliometric and qualitative analysis.

\subsection{Qualitative Content Analysis}

Sustainability factors were determined using bibliometric analysis [24,25]. Critical factors could be extracted using VOSviewer version 1.6.15, which creates complex and dynamic relationships in a single image. Since this paper focuses on the generated strategies from the identified factors, further reading for VOSviewer can be found in work by van Eck and Waltman [26]. This tool is effective for science mapping, visualizing a research theme, and text-mining analysis. The words were selected and chosen on the basis of their relevance, link strength, and frequency with sustainability in HEI. Higher strength and occurrence frequency represented leading and emerging research topics and trends in the field of sustainability in HEI $[27,28]$. Qualitative content analysis was used to find and connect the corresponding term taken from VOSviewer into the definition of sustainability factors. Bibliometric analysis could facilitate qualitative data analysis since it gave appropriate keywords (further defined as factors) that emerged from the research areas [29]. Qualitative content analysis consisted of summarizing, reorganizing, and reordering activity to explain the found factors [20]. The Mendeley Reference Manager was used to define the selected terms as a completed SWOT factor. There were 28 papers that were used for defining the selected terms of the SWOT factors. After the sustainabilityfactor binding terms for HEIs had been determined, all elements were defined and clustered into five HEI practice dimensions [18] and further analyzed using SWOT-QSPM. Related to sustainability factors of HEIs, Figure 1 show the steps for finding, identifying, and defining sustainability factors of higher-education institutions (HEIs).

\subsection{UNDIP Profile Data Collection}

The selection of UNDIP as a case study in the current research was based on criteria around data availability, the UI GreenMetric database, and best practices around the SDGs in the HEI context. All faculties, students, and other units have developed programs and activities to provide a comfortable, safe, healthy, and greener campus for all academic communities. Within 4 months (August-November 2020), various campus facilities and 
activities were observed that were thought to contribute to achieving the SDGs. Data were generated from direct surveys, interviews, and documentation.

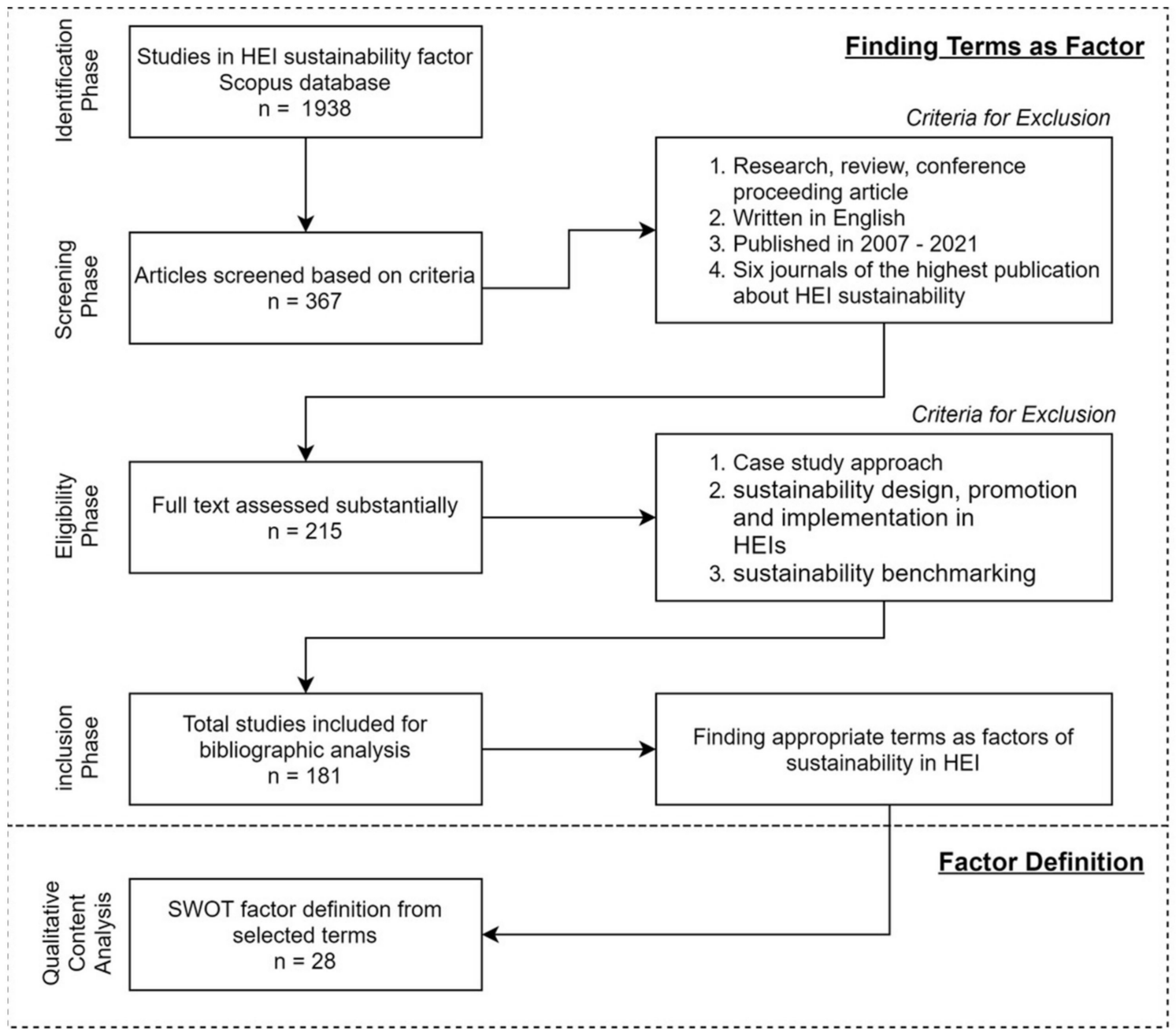

Figure 1. Steps for finding, identifying, and defining sustainability factors of higher-education institutions (HEIs).

\subsection{SWOT-QSPM Analysis}

SWOT analysis was used for strategic planning towards achieving campus sustainability, modified and adapted from previous studies [30,31]. In the SWOT-based strategy, 40 respondents from various policymaking parties regarding sustainability on campus participated in the survey. The specific criteria for the inclusion of respondents were as follows: (1) having participated in sustainability programs on campus for approximately 3 years; (2) having obtained at least an undergraduate level of education; and (3) being administrative staff, lecturers, or stakeholders.

Internal-factor evaluation (IFE) and external-factor evaluation (EFE) matrices were used to assess the weight of each internal and external factor. These matrices are important towards understanding which factors contribute the most to the system and towards determining the right strategy to address them. A SWOT factor flashcard was distributed to the respondents. Next, they were given a rank between 1 and 4 , where 1 and 2 represented a weakness or threat, and 3 and 4 represented a strength or opportunity for all factors. The factors were sorted and weighted on the basis of their relevance and effect on sustainability implementation in HEIs. The final score for each factor was determined by multiplying the relative weight and score. The overall score of the IFE and EFE matrices was calculated on the basis of the sum of the multiplied score. In the matrices, a mean score $>2.5$ meant 
that the organization was in the strength and opportunity position, and a mean score $<2.5$ indicated that the organization was in a weakness and threat position.

After IFE and EFE analysis, the position of the organization, whether in the strengththreat (ST), weakness-threat (WT), weakness-opportunity (WO), or strength-opportunity (SO) quadrant, along with its strategies, could be determined. Four pairwise strategies (ST, WT, WO, and SO) regarding the internal and external factors were considered and judged. Strengths-threats (ST) strategies mean that the organization's strategy to use internal strengths to decrease external threats is also considered to be a competitive strategy. Weaknesses-threats (WT) strategies are those that must be used by the organization facing external threats and internal weaknesses. These are also called defensive strategies. Weaknesses-opportunities (WO) strategies are considered to be conservative strategies because the organization utilizes external opportunities to compensate for a weakness. Strengths-opportunities (SO) strategies are aggressive strategies in which the organization uses external opportunities and exerts internal superiority for achieving sustainability [32]. Figure 2 shows the SWOT model of sustainability in HEI [33].

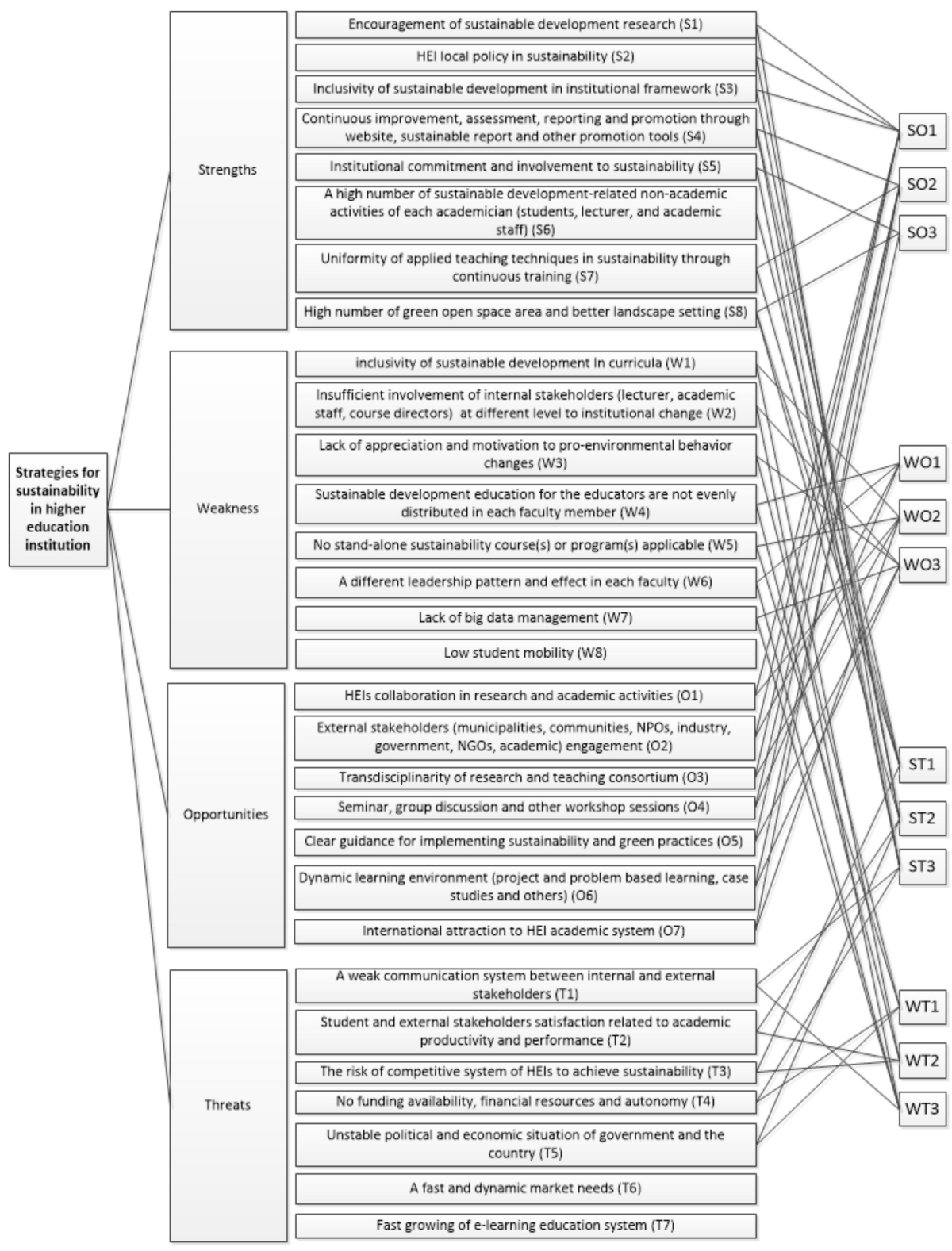

Figure 2. SWOT model of sustainability in HEI. 
The QSPM was used to evaluate and prioritize the strategy that was chosen. QSPM requires accurate judgment in the assessment of the applicability of a strategy proposed by the SWOT matrix. It has an attractiveness and weight score in each strategy to the factors. The attractiveness score (AS) is divided as follows: 1 is not attractive, 2 is less attractive, 3 is moderate, and 4 is very attractive. If a 1 was given, this indicated that the selected strategy was not affected by the factor item. If a 4 was given, this suggested that the chosen strategy was affected by the factor item. The weight of each factor was multiplied to obtain a total attractiveness score (ATS) that could then be evaluated for choosing the provided strategic priority. In this case, QSPM represents a powerful tool for quantitatively selecting and prioritizing strategies [34].

\section{Result}

\subsection{Sustainability Factors in HEI}

Research hotspots using co-occurrence mapping in VOSviewer can be used to identify and analyze the kinds of HEI sustainability factors that are globally studied by researchers. Among 181 papers, 5757 terms from the text data could be extracted for further analysis. When the minimal occurrence of the terms was set to 5,484 relevant terms met the threshold. Figure 3 outlines the terms that arose from the extracted metadata.

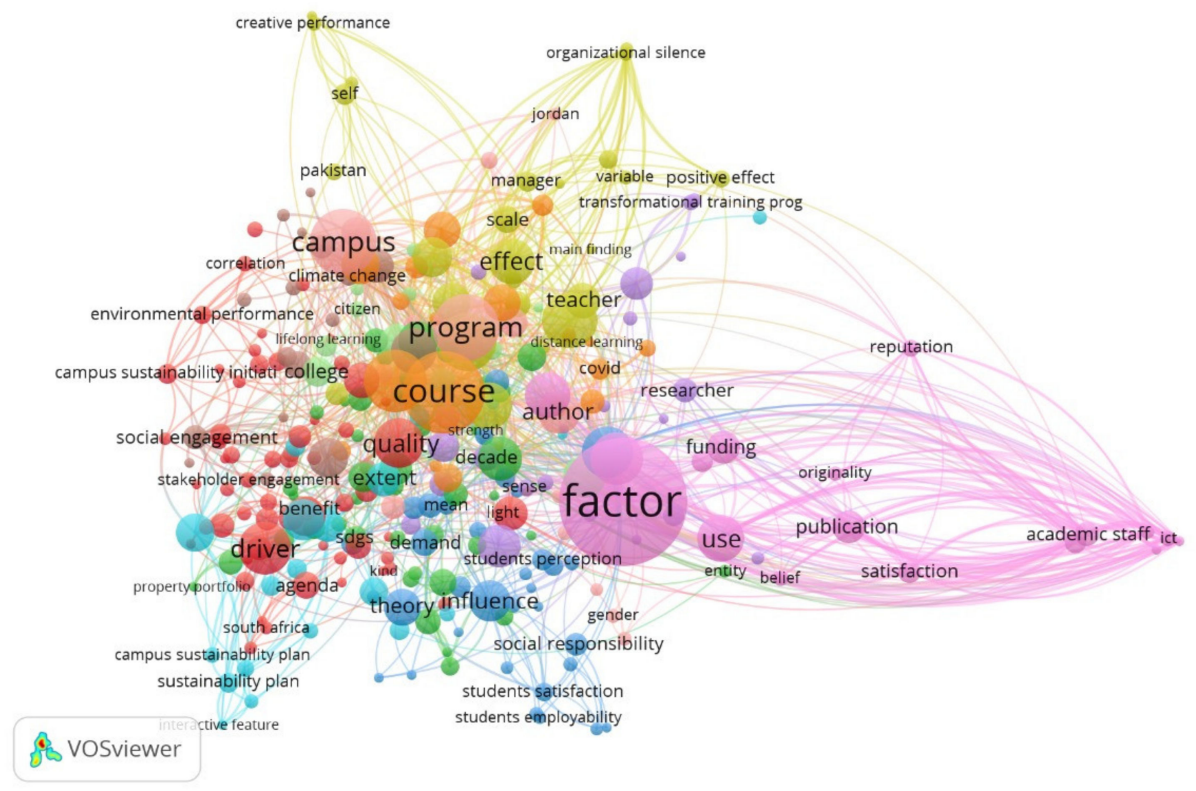

Figure 3. Co-occurrence terms in the network map of sustainability factors in HEIs.

The various factors that influenced sustainability were grouped back into five dimensions of sustainability implementation in higher education (see Table 1). Various kinds of methods, policies, socialization, and environmental campaigns are needed to change pro-environmental practices [35]. Additionally, the collaboration between HEIs in R\&D activities represents a forum for exchanging ideas, discussing and moving collaboratively between researchers at different universities to achieve the SDGs [36]. However, several key factors need to be sought as researchers continue to pay limited attention to these factors, such as the number of academic-community exchanges and the occurrence of transdisciplinary learning. Students are encouraged to undertake the learning process in a cross-disciplinary manner $[35,37]$.

\subsection{Strategies Enhancing Sustainability Implementation at UNDIP}

After understanding the influential factors, each factor was placed in the internaland external-factor evaluation matrix. The matrix was created to determine what kind of situation UNDIP currently faces. The normalized weight shown in Table 2 was obtained 
from the average estimated order of each factor that each respondent selected. The results of the evaluation of external and internal factors are given in Tables 2 and 3. In these tables, internal and external factors are 2646 and 2548, respectively. Each had a value of more than 2.5, which indicated that UNDIP must implement aggressive strategies to maximize opportunities and internal strength towards maintaining and improving sustainability practices.

Table 1. Sustainability factors in HEIs.

\begin{tabular}{|c|c|c|c|}
\hline Dimensions & Terms as Factors (Link Strength and Occurrence Frequency) & Factor Definition & References \\
\hline \multirow{8}{*}{$\begin{array}{l}\text { Teaching and } \\
\text { Learning }\end{array}$} & Internship $(90,9)$ & $\begin{array}{l}\text { Student, academic-staff, and lecturer } \\
\text { mobility and internship }\end{array}$ & {$[37,38]$} \\
\hline & University education, university curricula, and curriculum design $(419,19)$ & $\begin{array}{l}\text { Inclusivity of sustainable development } \\
\text { goals in curriculum design }\end{array}$ & {$[39,40]$} \\
\hline & Interactive features, technology education $(268,13)$ & Interactive teaching techniques & [41] \\
\hline & $\begin{array}{l}\text { Competence development, competency and transformational training, } \\
\text { transformational training program }(786,44)\end{array}$ & $\begin{array}{l}\text { Transformational training program and } \\
\text { competence development }\end{array}$ & {$[42,43]$} \\
\hline & Participatory approach, lifelong learning, higher learning $(395,22)$ & Dynamic learning environment & [44] \\
\hline & Quality orientation, management education $(401,22)$ & $\begin{array}{l}\text { Sustainable development education for the } \\
\text { educators }\end{array}$ & {$[45]$} \\
\hline & Departments, academic programs $(428,21)$ & $\begin{array}{l}\text { Stand-alone sustainability course(s) or } \\
\text { academic program }(\mathrm{s})\end{array}$ & [46] \\
\hline & Student perspective, academic performance, student satisfaction $(754,28)$ & $\begin{array}{l}\text { Student satisfaction related to academic } \\
\text { productivity and performance }\end{array}$ & [15] \\
\hline \multirow{4}{*}{ Research } & Transdisciplinary learning $(40,5)$ & $\begin{array}{l}\text { Transdisciplinary teaching consortium and } \\
\text { learning process }\end{array}$ & [35] \\
\hline & $\begin{array}{l}\text { Research productivity, plagiarism, publication, research activity and } \\
\text { performance }(3270,62)\end{array}$ & $\begin{array}{l}\text { Encouragement of sustainable } \\
\text { development research }\end{array}$ & [47] \\
\hline & Financial sustainability indicator, funding $(1282,36)$ & $\begin{array}{l}\text { Funding availability and financial } \\
\text { autonomy }\end{array}$ & [48] \\
\hline & Researcher, collaboration, international collaboration $(1954,70)$ & HEI collaboration in research activities & [36] \\
\hline \multirow{5}{*}{$\begin{array}{l}\text { Campus } \\
\text { Operation }\end{array}$} & Waste-management strategy, strategic agility, university policy $(987,23)$ & $\begin{array}{l}\text { HEI policy and strategy in sustainability } \\
\text { Sustainable-development-related }\end{array}$ & [49] \\
\hline & $\begin{array}{l}\text { Sustainability effort, waste management, waste minimization, recycling, } \\
\text { sustainability activity }(1151,58)\end{array}$ & $\begin{array}{l}\text { nonacademic activities of each } \\
\text { academician (students, lecturers, and } \\
\text { academic staff) }\end{array}$ & {$[50]$} \\
\hline & Organizational sustainability, organizational culture, institutionalization $(319,16)$ & $\begin{array}{l}\text { Inclusivity of sustainable development } \\
\text { goals in the institutional framework }\end{array}$ & [51] \\
\hline & Job satisfaction, academic staff, institutional change $(2107,28)$ & $\begin{array}{l}\text { Involvement of internal stakeholders } \\
\text { (lecturers, academic staff, course directors) } \\
\text { at a different level to institutional change }\end{array}$ & [22] \\
\hline & $\begin{array}{l}\text { Heterogeneity, international students, environmental worldview, } \\
\text { internationalization }(852,50)\end{array}$ & $\begin{array}{l}\text { International attraction to HEI academic } \\
\text { system }\end{array}$ & [48] \\
\hline \multirow{6}{*}{ Outreach } & Community engagement, social engagement, stakeholder engagement $(735,30)$ & $\begin{array}{l}\text { External stakeholders (municipalities, } \\
\text { communities, NPOs, industry, government, } \\
\text { NGOs, academia) engagement }\end{array}$ & [37] \\
\hline & Loyalty $(705,22)$ & $\begin{array}{l}\text { Institutional commitment to achieve } \\
\text { sustainable development goals }\end{array}$ & {$[52,53]$} \\
\hline & $\begin{array}{l}\text { Academic leaders, university leaders, sustainability leadership, and leadership } \\
(970,42)\end{array}$ & $\begin{array}{l}\text { Leadership pattern and its effect on } \\
\text { sustainability }\end{array}$ & [36] \\
\hline & Environmental legitimacy, communication $(738,35)$ & $\begin{array}{l}\text { Environmental legitimacy and } \\
\text { communication system between internal } \\
\text { and external stakeholders }\end{array}$ & [54] \\
\hline & $\begin{array}{l}\text { Water, transportation, energy consumption, energy efficiency, infrastructure, and } \\
\text { green university }(1217,60)\end{array}$ & $\begin{array}{l}\text { Morphological characteristics including } \\
\text { landscape setting and green infrastructure }\end{array}$ & {$[15,55]$} \\
\hline & $\begin{array}{l}\text { Employability, student employability, graduate employability, and labor market } \\
(536,29)\end{array}$ & Student employability and market needs & {$[43,56]$} \\
\hline \multirow{6}{*}{ Administration } & $\begin{array}{l}\text { Sustainability assessment, environmental performance, EMS practices, } \\
\text { sustainability reporting }(1030,65)\end{array}$ & $\begin{array}{l}\text { Continuous improvement, assessment, } \\
\text { reporting, and promotion }\end{array}$ & [36] \\
\hline & Data analysis, web, website, quality management $(984,43)$ & Website and extensive data management & {$[57,58]$} \\
\hline & Sustainability plan, campus sustainability plan, guidelines $(940,42)$ & $\begin{array}{l}\text { Clear guidance for implementing } \\
\text { sustainability and green practices }\end{array}$ & {$[59]$} \\
\hline & $\begin{array}{l}\text { Reputation, corporate reputation, competitiveness, and competitive advantage } \\
(855,33)\end{array}$ & $\begin{array}{l}\text { HEI reputation and competition to achieve } \\
\text { sustainability }\end{array}$ & [48] \\
\hline & Sustainability governance, political skill $(165,12)$ & The political stability of the government & [54] \\
\hline & Digital innovation, distance education, online learning $(241,16)$ & $\begin{array}{l}\text { Fast-growing of distance and e-learning } \\
\text { education system }\end{array}$ & {$[60]$} \\
\hline
\end{tabular}


Table 2. Summary of internal-factor evaluation.

\begin{tabular}{|c|c|c|c|c|c|}
\hline No & Code & Factors & Normalized Weight & Rank & Weighted Score \\
\hline 1 & S1 & Encouragement of sustainable-development research & 0.072 & 4 & 0.287 \\
\hline 2 & S2 & HEI policy and strategy in sustainability & 0.072 & 4 & 0.287 \\
\hline 3 & S3 & $\begin{array}{l}\text { Inclusivity of Sustainable Development Goals in the institutional } \\
\text { framework }\end{array}$ & 0.072 & 4 & 0.287 \\
\hline 4 & S4 & Continuous improvement, assessment, reporting, and promotion & 0.067 & 3 & 0.201 \\
\hline 5 & S5 & Institutional commitment to Sustainable Development Goals & 0.104 & 4 & 0.417 \\
\hline 6 & S6 & $\begin{array}{l}\text { Sustainable-development-related nonacademic activities of each } \\
\text { academician (students, lecturers, and academic staff) }\end{array}$ & 0.046 & 3 & 0.139 \\
\hline 7 & S7 & $\begin{array}{l}\text { Morphological characteristics including landscape setting and green } \\
\text { infrastructure }\end{array}$ & 0.021 & 3 & 0.063 \\
\hline 8 & S8 & Interactive teaching techniques & 0.046 & 4 & 0.185 \\
\hline 9 & W1 & Inclusivity of sustainable development goals in curriculum design & 0.060 & 1 & 0.060 \\
\hline 10 & W2 & $\begin{array}{l}\text { Involvement of internal stakeholders (lecturers, academic staff, course } \\
\text { directors) at a different level to institutional change }\end{array}$ & 0.095 & 2 & 0.190 \\
\hline 11 & W3 & $\begin{array}{l}\text { Lack of appreciation and motivation to pro-environmental behavior } \\
\text { changes }\end{array}$ & 0.067 & 2 & 0.134 \\
\hline 12 & W4 & Sustainable-development education for educators & 0.044 & 1 & 0.044 \\
\hline 13 & W5 & Stand-alone sustainability course(s) or academic program(s) & 0.053 & 1 & 0.053 \\
\hline 14 & W6 & Leadership pattern and its effect on sustainability & 0.058 & 2 & 0.116 \\
\hline 15 & W7 & Website and big-data management & 0.063 & 1 & 0.063 \\
\hline \multirow[t]{2}{*}{16} & W8 & Student, academic-staff, and lecturer mobility and internship & 0.060 & 2 & 0.120 \\
\hline & & IFE & 1 & & 2.646 \\
\hline
\end{tabular}

Table 3. Summary of external-factor evaluation.

\begin{tabular}{|c|c|c|c|c|c|}
\hline No & Code & Factors & Normalized Weight & Rank & Weighted Score \\
\hline 1 & O1 & HEI collaboration in research activities & 0.104 & 4 & 0.417 \\
\hline 2 & $\mathrm{O} 2$ & $\begin{array}{l}\text { External stakeholders (municipalities, communities, NPOs, } \\
\text { industry, government, NGOs, academia) engagement }\end{array}$ & 0.080 & 3 & 0.241 \\
\hline 3 & $\mathrm{O} 3$ & Transdisciplinary teaching consortium and learning process & 0.068 & 4 & 0.274 \\
\hline 4 & $\mathrm{O} 4$ & $\begin{array}{l}\text { Transformational training program and competence } \\
\text { development }\end{array}$ & 0.048 & 3 & 0.143 \\
\hline 5 & O5 & $\begin{array}{l}\text { Clear guidance for implementing sustainability and green } \\
\text { practices }\end{array}$ & 0.101 & 4 & 0.405 \\
\hline 6 & O6 & Dynamic learning environment & 0.060 & 3 & 0.179 \\
\hline 7 & O7 & International attraction to HEI academic system & 0.039 & 3 & 0.116 \\
\hline 8 & $\mathrm{~T} 1$ & $\begin{array}{l}\text { Environmental legitimacy and communication system } \\
\text { between internal and external stakeholders }\end{array}$ & 0.089 & 2 & 0.179 \\
\hline 9 & $\mathrm{~T} 2$ & $\begin{array}{l}\text { Student satisfaction related to academic productivity and } \\
\text { performance }\end{array}$ & 0.086 & 2 & 0.173 \\
\hline 10 & $\mathrm{~T} 3$ & HEI reputation and competition to achieve sustainability & 0.074 & 1 & 0.074 \\
\hline 11 & $\mathrm{~T} 4$ & Funding availability and financial autonomy & 0.098 & 2 & 0.196 \\
\hline 12 & T5 & Political stability of government & 0.039 & 1 & 0.039 \\
\hline 13 & T6 & Student employability and market needs & 0.048 & 1 & 0.048 \\
\hline \multirow[t]{2}{*}{14} & T7 & Fast-growing distance and e-learning education system & 0.065 & 1 & 0.065 \\
\hline & & EFE & 1 & & 2.548 \\
\hline
\end{tabular}

On the basis of internal-factor evaluation, institutional commitment to the SDGs was the most crucial strength factor, while continuous improvement, assessment, reporting, and promotion were less critical strength factors. Internal stakeholders' involvement at various levels to institutional change and sustainable-development education for educators were considered to be the most important and insignificant weakness factors, respectively, among all weakness factors.

HEI collaboration in research activities was found to be the most essential opportunities factor. IFE and EFE analyses found that UNDIP currently needs to implement aggressive strategies in response to emerging sustainability factors. The summary of the internal factors was higher than that for the external factors, indicating the potential of inner strength, which needs to be re-explored in implementing sustainability. Table 4 shows strategies that need to be implemented by UNDIP towards achieving sustainability.

Table 5 shows that the highest strategic priority was "fostering external collaboration in research, community development, and education programs" (5097), followed 
by "implementing the Plan-Do-Check-Act (PDCA) tool for continuous improvement in teaching and education ecosystems" (4983) and "simultaneously promoting academic and nonacademic HEI systems to external stakeholders" (4277).

Table 4. Organization position and SWOT strategies.

\begin{tabular}{|c|c|}
\hline $\begin{array}{l}\text { Conservative strategies (WO) } \\
\text { 1. Conducting seminars, workshops, and training for trainer programs, which } \\
\text { are lectures by professionals inside and outside HEIs related to sustainability } \\
\text { implementation in higher education } \\
\text { 2. Creating fundamental sustainability through open and closed courses or } \\
\text { programs that are taught by a multi- and transdisciplinary educator } \\
\text { (cross-teaching) } \\
\text { 3. Establishing gamification (award and punishment) systems in the } \\
\text { sustainability implementation of internal stakeholders }\end{array}$ & $\begin{array}{l}\text { Aggressive Strategies (SO) } \\
\text { 1. Fostering external collaboration in research, community development, and } \\
\text { education programs } \\
\text { 2. Simultaneously promoting academic and nonacademic HEI systems to } \\
\text { external stakeholders } \\
\text { 3. Implementing the Plan-Do-Check-Act tool for continuous improvement in } \\
\text { teaching and education ecosystems }\end{array}$ \\
\hline $\begin{array}{l}\text { Defensive Strategies (WT) } \\
\text { 1. Improving nominal budgets of sustainability-research and } \\
\text { community-development programs } \\
\text { 2. Implementing and improving accountability and good-governance programs } \\
\text { 3. Downsizing organizational systems for effective resource management }\end{array}$ & $\begin{array}{l}\text { Competitive Strategies (ST) } \\
\text { 1. Adding more physical and nonphysical infrastructure related to } \\
\text { sustainability programs } \\
\text { 2. Intensifying academic-quality assurance systems } \\
\text { 3. Strengthening cooperative systems between HEI and commercializing } \\
\text { research output }\end{array}$ \\
\hline
\end{tabular}

Table 5. Quantitative strategic-planning matrix.

\begin{tabular}{|c|c|c|c|c|c|c|c|}
\hline \multirow{2}{*}{$\begin{array}{l}\text { Sustainability } \\
\text { Factors }\end{array}$} & \multirow{2}{*}{$\begin{array}{l}\text { Normalized } \\
\text { Weight }\end{array}$} & \multicolumn{2}{|c|}{ First Strategy } & \multicolumn{2}{|c|}{ Second Strategy } & \multicolumn{2}{|c|}{ Third Strategy } \\
\hline & & AS & TAS 1 & AS & TAS 2 & AS & TAS 3 \\
\hline S1 & 0.072 & 3 & 0.215 & 4 & 0.287 & 4 & 0.287 \\
\hline S2 & 0.072 & 3 & 0.215 & 2 & 0.144 & 4 & 0.287 \\
\hline S3 & 0.072 & 4 & 0.287 & 2 & 0.144 & 2 & 0.144 \\
\hline S4 & 0.067 & 2 & 0.134 & 2 & 0.134 & 4 & 0.269 \\
\hline S5 & 0.104 & 4 & 0.417 & 2 & 0.208 & 4 & 0.417 \\
\hline S6 & 0.046 & 4 & 0.185 & 3 & 0.139 & 2 & 0.093 \\
\hline S7 & 0.021 & 1 & 0.021 & 2 & 0.042 & 2 & 0.042 \\
\hline S8 & 0.046 & 2 & 0.093 & 3 & 0.139 & 3 & 0.139 \\
\hline W1 & 0.060 & 2 & 0.120 & 2 & 0.120 & 4 & 0.241 \\
\hline W2 & 0.095 & 3 & 0.285 & 1 & 0.095 & 4 & 0.380 \\
\hline W3 & 0.067 & 3 & 0.201 & 2 & 0.134 & 2 & 0.134 \\
\hline W4 & 0.044 & 3 & 0.132 & 2 & 0.088 & 2 & 0.088 \\
\hline W5 & 0.053 & 3 & 0.160 & 2 & 0.106 & 2 & 0.106 \\
\hline W6 & 0.058 & 2 & 0.116 & 1 & 0.058 & 2 & 0.116 \\
\hline W7 & 0.063 & 1 & 0.063 & 2 & 0.125 & 2 & 0.125 \\
\hline W8 & 0.060 & 2 & 0.120 & 2 & 0.120 & 2 & 0.120 \\
\hline $\mathrm{O} 1$ & 0.104 & 4 & 0.417 & 2 & 0.208 & 3 & 0.313 \\
\hline $\mathrm{O} 2$ & 0.080 & 2 & 0.161 & 3 & 0.241 & 1 & 0.080 \\
\hline $\mathrm{O} 3$ & 0.068 & 4 & 0.274 & 2 & 0.137 & 3 & 0.205 \\
\hline $\mathrm{O} 4$ & 0.048 & 3 & 0.143 & 2 & 0.095 & 1 & 0.048 \\
\hline O5 & 0.101 & 3 & 0.304 & 2 & 0.202 & 3 & 0.304 \\
\hline O6 & 0.060 & 2 & 0.119 & 3 & 0.179 & 3 & 0.179 \\
\hline O7 & 0.039 & 3 & 0.116 & 3 & 0.116 & 2 & 0.077 \\
\hline $\mathrm{T} 1$ & 0.089 & 1 & 0.089 & 2 & 0.179 & 1 & 0.089 \\
\hline $\mathrm{T} 2$ & 0.086 & 2 & 0.173 & 3 & 0.259 & 2 & 0.173 \\
\hline T3 & 0.074 & 3 & 0.223 & 2 & 0.149 & 2 & 0.149 \\
\hline $\mathrm{T} 4$ & 0.098 & 1 & 0.098 & 1 & 0.098 & 1 & 0.098 \\
\hline T5 & 0.039 & 1 & 0.039 & 1 & 0.039 & 1 & 0.039 \\
\hline T6 & 0.048 & 1 & 0.048 & 2 & 0.095 & 1 & 0.048 \\
\hline $\mathrm{T} 7$ & 0.065 & 2 & 0.131 & 3 & 0.196 & 3 & 0.196 \\
\hline \multicolumn{2}{|c|}{ TAS for Each Strategy } & & 5.097 & & 4.277 & & 4.983 \\
\hline
\end{tabular}

\section{Discussion}

The education system, especially in higher education, bears their responsibility for the sustainability crisis because educational institutions produce different kinds of leadership that drive society and the economy, and establish a consumer culture that is not sustainable [61]. Higher education is now required to provide graduates who are able to face environmental, social, and economic challenges through the provision of competencies, skills, and knowledge [62]. These are some of the greatest intellectual, ethical, and political challenges that higher education has ever faced, given that teaching and learning about sustainability has declined since 2001 [63]. Meanwhile, sustainability challenges 
the paradigm, structure, and key practices in higher education [64]. However, educating citizens to a higher level does not necessarily lead to higher levels of thinking and living in terms of sustainability. Still, there is a lack of comparative studies showing various trends related to sustainability processes in and impact on higher education [65].

This comparative study focuses on using bibliometric analysis methods to summarize and synthesize the findings of a research study on a particular topic. In bibliometric analysis, the assumption is to identify everything that was published in a region or a particular research topic that reported quantitative results [66]. The identification results of the entire analysis are then weighed and collected to summarize an overall result. On the basis of bibliometric-analysis results, aggressive strategies were considered to establish UNDIP sustainability. The highest strategic priority was "fostering external collaboration in research, community-development, and education programs" (5097), followed by "implementing the Plan-Do-Check-Act tool for continuous improvement in teaching and education ecosystem" (4983) and "simultaneously promoting academic and nonacademic HEI systems to external stakeholders" (4277).

\subsection{Fostering External Collaboration in Research, Community-Development, and Education Programs}

Activities at the university, in community agencies, and companies are engaged in sustainable development [67]. Involving students in learning activities, both in collaborative learning and service learning, is needed to improve student commitment and encourage pro-environmental behavior. The students perceive group work packaged in collaborative learning as a dynamic method that encourages communication skills, personal relationships, and motivation [68]. The universities also suggested offering a service-learning methodology in which students become more involved in their learning process and are helped in improving their social commitment to pro-environmental behavior [69]. The collaborative-learning and strategic approach has led to several sustainability projects in research, local-community development, and education. All sectors, including universities, companies, and local communities, are equally important to the achievement of sustainable development. HEIs may obtain their strategies in collaborative learning and development. The ERSCP and EMSU conference held in Delft, The Netherlands found that collaboration in knowledge, learning, and participation often affects sustainable innovation and consumption [70].

In term or energy, the contribution of solar panels as a renewable-energy source at UNDIP is enormous because they can provide electricity at $1209.8 \mathrm{kWh}$. The slightest assistance of renewable energy is provided by the combined heat-chiller power plant, which only accounts for $5 \%$ of total renewable energy from UNDIP. The annual contribution of renewable energy in providing electrical power for UNDIP activities is only $0.02 \%$. However, the electricity needs of UNDIP are still vast; its 2020 electricity consumption was recorded at 11,565,046.6 $\mathrm{kWh}$. This significant amount of energy consumption can be reduced by implementing environmentally friendly smart buildings, where electricity consumption in 2019 was reduced by $30 \%$ in 2020 .

\subsection{Implementing Plan-Do-Check-Act Tool for Continuous Improvement in Teaching and Education Ecosystems}

As applied in HEIs, continuous improvement involves the whole organization in improving quality and management principles [71] by implementing continuous improvement using Plan-Do-Check-Act (PDCA). At university, the promotion of quality-assurance systems is in great demand. The PDCA cycle was therefore repeated to improve the quality of the education program. The PDCA cycle ensures and improves the quality of education created for students to achieve their learning goals [72]. With the purpose of underpinning the quality assurance of a class curriculum, the PDCA cycle applied in UNDIP would result in improved education quality through which students can achieve sustainability in their learning. 
As a form of adherence to the SDGs pledged in 2015, UNDIP has improved its SDG indicators. UI GreenMetric is considered to be one method of measuring and providing benchmarks towards achieving SDGs at the university level. The form of continual improvement can be seen from the increase in each UI GreenMetric indicator score every year for the period of 2017-2020. A study was conducted with a bibliometric approach to provide information on intellectual structures, conceptual dynamics, knowledge sharing, and development regarding rapidly developing education and research trends with core authors, top journals, countries, and leading universities, including UNDIP [73]. This practice forms part of an evaluation of the education sector and sustainability research that has globally increased.

UNDIP carries out plastic waste reduction activities, which include the application of several methods. The first method ensures that single-use plastic drink bottles are not in use on campus. Students, staff, and campus stakeholders must bring their respective environmentally friendly refillable drink bottles or tumblers. The involvement of people and their behavior constitutes responsibility for creating and maintaining a green campus in terms of recycling and waste-minimization programs on campus [11]. This aspect is essential but complex for campus sustainability, and includes operations, research, students, staff, stakeholders, education, teaching, a collaboration between institutions, and sustainability reporting [47]. The second method, meeting activities and student activities in mass gatherings, ensures that drinks and food are not packaged in plastic [74].

\subsection{Promoting Institutional Systems to External Stakeholders}

Growing institutional systems are generally influenced by the involvement of staff, beneficiaries, and other stakeholders [62]. Stakeholders may take possession of new initiatives and help design the institutional systems relevant to their needs [71]. Most threats and opportunities that occur in institutions are estimated to affect the long-term development of institutions and define their sustainability [32]. UNDIP, as a WCU, aspires in the long term to have reliable or 'wide' infrastructure (diverse, complete, smart, anticipatory, comprehensive, and productive) that can effectively and efficiently support all functions and activities the UNDIP's community undertakes. The establishment of the UNDIP Marine Science Techno Park (MSTP) is infrastructural development that was conducted to meet the campus's multidisciplinary needs. MSTP stands on 52 hectares and is located in Teluk Awur, Jepara Regency, Central Java, Indonesia. Various facilities and infrastructural developments were provided at MSTP to support R\&D and the implementation of innovations that are ready to be commercialized. MSTP is also an incubation system of new entrepreneurial growth based on marine technology and collaboration facilities among industry, government, and academics towards accelerating the commercialization of various research findings.

\section{Conclusions}

A sustainability model for HEIs was successfully developed using UNDIP as a case study. Sustainability success in HEIs was determined to be influenced by 30 factors that are divided into five primary dimensions: teaching and learning, research, campus operations, administration, and outreach. Of the five dimensions, most of the identified factors by bibliometric analysis could be found within the teaching and learning dimension. However, researcher outreach was the dimension that was most frequently discussed with respect to sustainability on campus, particularly in terms of pro-environmental behavior and green infrastructure factors in HEIs. Institutional commitment to SDGs and HEI collaboration in research activities were identified as the most influential internal and external factors at UNDIP, with the same score of 0.417. On the basis of IFE and EFE scores, UNDIP currently sits in the strengths-opportunities (SO) quadrant, indicating that aggressive strategies need to be conducted so that UNDIP can properly implement sustainability practices. SWOT analysis revealed that the strategy of "fostering external collaboration in research, community-development, and education programs" represents the primary strategy that 
UNDIP must implement. Importantly, the current study is limited to UNDIP, which means comparative analyses with the sustainability implementation of other HEIs are needed, and these can be examined using the identified factors in this study.

Author Contributions: Conceptualization, M.A.B.; methodology, B.S.R.; software, F.I.M. and I.F.S.W.; validation, S.A.P.; formal analysis, B.S.R.; investigation, S.A.P.; resources, S.A.P. and B.S.R.; data curation, B.S.R. and I.F.S.W.; writing—original draft preparation, F.I.M. and B.S.R.; writing—review and editing, M.A.B.; visualization, I.F.S.W.; supervision, M.A.B.; project administration, F.I.M. All authors have read and agreed to the published version of the manuscript.

Funding: This research was funded by the SAPBN UNDIP, grant number 387-06/UN7.P4.3/PP/2018 and DRPM under grant number 225-109/UN7.6.1/PP/2020.

Acknowledgments: The authors are grateful to Sheila Nurul Adhana, Ayunda Rahmadhani, and Julia Nur Rizkiana for their help on facilitating focus group discussion for this research.

Conflicts of Interest: The authors declare no conflict of interest.

\section{References}

1. Díaz-Iso, A.; Eizaguirre, A.; García-Olalla, A. Extracurricular activities in higher education and the promotion of reflective learning for sustainability. Sustainability 2019, 11, 4521. [CrossRef]

2. Ngang, T.K.; Hashim, N.H.; Yunus, H.M. Novice Teacher Perceptions of the Soft Skills Needed in Today's Workplace. Procedia Soc. Behav. Sci. 2015, 177, 284-288. [CrossRef]

3. Butt, L.; More, E.; Avery, G.C. The myth of the "green student": Student involvement in Australian university sustainability programmes. Stud. High. Educ. 2014, 39, 786-804. [CrossRef]

4. Zhu, Y.; Wang, F.; Yan, J. The Potential of Distributed Energy Resources in Building Sustainable Campus: The Case of Sichuan University. Energy Procedia 2018, 145, 582-585. [CrossRef]

5. Burford, G.; Hoover, E.; Velasco, I.; Janoušková, S.; Jimenez, A.; Piggot, G.; Podger, D.; Harder, M.K. Bringing the "Missing Pillar" into sustainable development goals: Towards intersubjective values-based indicators. Sustainability 2013, 5, 3035-3059. [CrossRef]

6. Sales de Aguiar, T.R.; Paterson, A.S. Sustainability on campus: Knowledge creation through social and environmental reporting. Stud. High. Educ. 2018, 43, 1882-1894. [CrossRef]

7. Abubakar, I.R.; Aina, Y.A.; Alshuwaikhat, H.M. Sustainable development at Saudi Arabian universities: An overview of institutional frameworks. Sustainability 2020, 12, 8008. [CrossRef]

8. Sima, M.; Grigorescu, I.; Bălteanu, D. An overview of campus greening initiatives at universities in Romania. Int. J. Sustain. High. Educ. 2019, 20, 410-422. [CrossRef]

9. Fissi, S.; Romolini, A.; Gori, E.; Contri, M. The path toward a sustainable green university: The case of the University of Florence. J. Clean. Prod. 2021, 279, 123655. [CrossRef]

10. Lo-Iacono-Ferreira, V.G.; Capuz-Rizo, S.F.; Torregrosa-López, J.I. Key Performance Indicators to optimize the environmental performance of Higher Education Institutions with environmental management system-A case study of Universitat Politècnica de València. J. Clean. Prod. 2018, 178, 846-865. [CrossRef]

11. Moqbel, S.; Abu-Zurayk, R.; Bozeya, A.; Alsisan, R.; Al Bawab, A. Assessment of sustainable recycling at The University of Jordan. Int. J. Sustain. High. Educ. 2020, 21, 1111-1129. [CrossRef]

12. Okanović, A.; Ješić, J.; Đaković, V.; Vukadinović, S.; Panić, A.A. Increasing university competitiveness through assessment of green content in curriculum and eco-labeling in higher education. Sustainability 2021, 13, 712. [CrossRef]

13. Wang, Y.; Shi, H.; Sun, M.; Huisingh, D.; Hansson, L.; Wang, R. Moving towards an ecologically sound society? Starting from green universities and environmental higher education. J. Clean. Prod. 2013, 61, 1-5. [CrossRef]

14. Muñoz-Suárez, M.; Guadalajara, N.; Osca, J.M. A comparative analysis between global university rankings and environmental sustainability of universities. Sustainability 2020, 12, 5759. [CrossRef]

15. Atici, K.B.; Yasayacak, G.; Yildiz, Y.; Ulucan, A. Green University and academic performance: An empirical study on UI GreenMetric and World University Rankings. J. Clean. Prod. 2020, 291, 125289. [CrossRef]

16. Lourrinx, E.; Budihardjo, M.A. Implementation of UI GreenMetric at Diponegoro University in order to Environmental Sustainability Efforts. E3S Web Conf. 2019, 125, 02007. [CrossRef]

17. Ambariyanto, A.; Utama, Y.J.; Budihardjo, M.A.; Purwanto, P. Undip Initiative for Sustainability (UNITY): A University Sustainability Program. E3S Web Conf. 2018, 73, 9-11. [CrossRef]

18. Kapitulčinová, D.; AtKisson, A.; Perdue, J.; Will, M. Towards integrated sustainability in higher education-Mapping the use of the Accelerator toolset in all dimensions of university practice. J. Clean. Prod. 2017, 172, 4367-4382. [CrossRef]

19. Piwowar-Sulej, K.; Krzywonos, M.; Kwil, I. Environmental entrepreneurship-Bibliometric and content analysis of the subject literature based on H-Core. J. Clean. Prod. 2021, 295, 126227. [CrossRef]

20. Cavalieri, A.; Reis, J.; Amorim, M. Circular economy and internet of things: Mapping science of case studies in manufacturing industry. Sustainability 2021, 13, 3299. [CrossRef] 
21. Page, M.J.; McKenzie, J.E.; Bossuyt, P.M.; Boutron, I.; Hoffmann, T.C.; Mulrow, C.D.; Shamseer, L.; Tetzlaff, J.M.; Akl, E.A.; Brennan, S.E.; et al. The PRISMA 2020 statement: An updated guideline for reporting systematic reviews. Int. J. Surg. 2021, 88, 1-11. [CrossRef] [PubMed]

22. Figueiró, P.S.; Raufflet, E. Sustainability in higher education: A systematic review with focus on management education. J. Clean. Prod. 2015, 106, 22-33. [CrossRef]

23. Abad-Segura, E.; González-Zamar, M.-D.; Infante-Moro, J.C.; García, G.R. Sustainable management of digital transformation in higher education: Global research trends. Sustainability 2020, 12, 2107. [CrossRef]

24. Sharifi, A. Urban sustainability assessment: An overview and bibliometric analysis. Ecol. Indic. 2021, 121, 107102. [CrossRef]

25. Liao, H.; Tang, M.; Luo, L.; Li, C.; Chiclana, F.; Zeng, X.J. A bibliometric analysis and visualization of medical big data research. Sustainability 2018, 10, 166. [CrossRef]

26. Van Eck, N.J.; Waltman, L. Software survey: VOSviewer, a computer program for bibliometric mapping. Scientometrics 2010, 84, 523-538. [CrossRef] [PubMed]

27. Lis, A.; Tomanek, M. Sport management: Thematic mapping of the research field. J. Phys. Educ. Sport 2020, 20, 1201-1208.

28. Chen, S.; Lu, Q.; Bai, J.; Deng, C.; Wang, Y.; Zhao, Y. Global publications on stigma between 1998-2018: A bibliometric analysis. J. Affect. Disord. 2020, 274, 363-371. [CrossRef]

29. Corallo, A.; Latino, M.E.; Menegoli, M.; De Devitiis, B.; Viscecchia, R. Human factor in food label design to support consumer healthcare and safety: A systematic literature review. Sustainability 2019, 11, 4019. [CrossRef]

30. Rezazadeh, S.; Jahani, A.; Makhdoum, M.; Meigooni, H.G. Evaluation of the Strategic Factors of the Management of Protected Areas Using SWOT Analysis-Case Study: Bashgol Protected Area-Qazvin Province. Open J. Ecol. 2017, 07, 55-68. [CrossRef]

31. Abbasi, E.; Vahdani, F.A.; Ahmadi, S.H.; Behrouz, R. Developing and ranking strategies for machinery companies via QSPM and SWOT matrix: A case study in Toolid Atash machinery company. Nat. Soc. Sci. 2013, 2, 452-461.

32. Xin-gang, Z.; Yi-sheng, Y.; Tian-tian, F.; Yu-heng, Y. International cooperation on renewable energy electricity in China - A critical analysis. Renew. Energy 2013, 55, 410-416. [CrossRef]

33. Shahabi, R.S.; Basiri, M.H.; Kahag, M.R.; Zonouzi, S.A. An ANP-SWOT approach for interdependency analysis and prioritizing the Iran's steel scrap industry strategies. Resour. Policy 2014, 42, 18-26. [CrossRef]

34. Fan, T.; Xue, D.Q. Sustainable development of cultural industry in Shaanxi Province of Northwest China: A SWOT and AHP analysis. Sustainability 2018, 10, 2830. [CrossRef]

35. Viegas, C.V.; Bond, A.J.; Vaz, C.R.; Borchardt, M.; Pereira, G.M.; Selig, P.M.; Varvakis, G. Critical attributes of Sustainability in Higher Education: A categorisation from literature review. J. Clean. Prod. 2016, 126, 260-276. [CrossRef]

36. Gómez, F.U.; Sáez-Navarrete, C.; Lioi, S.R.; Marzuca, V.I. Adaptable model for assessing sustainability in higher education. J. Clean. Prod. 2015, 107, 475-485. [CrossRef]

37. Beynaghi, A.; Trencher, G.; Moztarzadeh, F.; Mozafari, M.; Maknoon, R.; Leal Filho, W. Future sustainability scenarios for universities: Moving beyond the United Nations Decade of Education for Sustainable Development. J. Clean. Prod. 2016, 112, 3464-3478. [CrossRef]

38. García-Casarejos, N.; Sáez-Pérez, L.A. Internships for higher education students to promote the local sustainability of rural places. Sustainability 2020, 12, 4926. [CrossRef]

39. Ramos, T.B.; Caeiro, S.; Van Hoof, B.; Lozano, R.; Huisingh, D.; Ceulemans, K. Experiences from the implementation of sustainable development in higher education institutions: Environmental Management for Sustainable Universities. J. Clean. Prod. 2015, 106, 3-10. [CrossRef]

40. Hill, L.M.; Wang, D. Integrating sustainability learning outcomes into a university curriculum: A case study of institutional dynamics. Int. J. Sustain. High. Educ. 2018, 19, 699-720. [CrossRef]

41. Varouchas, E.; Sicilia, M.; Sánchez-Alonso, S. Academics' perceptions on quality in higher education shaping key performance indicators. Sustainability 2018, 10, 4752. [CrossRef]

42. Al Qudah, N.F.; Yang, Y.; Anjum, M.A. Transformational training programs and quality orientation of employees: Does employees' loyalty matter? Sustainability 2018, 10, 465. [CrossRef]

43. Abelha, M.; Fernandes, S.; Mesquita, D.; Seabra, F.; Ferreira-Oliveira, A.T. Graduate employability and competence development in higher education-A systematic literature review using PRISMA. Sustainability 2020, 12, 5900. [CrossRef]

44. Barnard, Z.; Van der Merwe, D. Innovative management for organizational sustainability in higher education. Int. J. Sustain. High. Educ. 2016, 17, 208-227. [CrossRef]

45. Lambrechts, W.; Verhulst, E.; Rymenams, S. Professional development of sustainability competences in higher education: The role of empowerment. Int. J. Sustain. High. Educ. 2017, 18, 697-714. [CrossRef]

46. Rusinko, C.A. Integrating sustainability in higher education: A generic matrix. Int. J. Sustain. High. Educ. 2010, 11, 250-259. [CrossRef]

47. Lozano, R.; Lukman, R.; Lozano, F.J.; Huisingh, D.; Lambrechts, W. Declarations for sustainability in higher education: Becoming better leaders, through addressing the university system. J. Clean. Prod. 2013, 48, 10-19. [CrossRef]

48. Aleixo, A.M.; Leal, S.; Azeiteiro, U.M. Conceptualization of sustainable higher education institutions, roles, barriers, and challenges for sustainability: An exploratory study in Portugal. J. Clean. Prod. 2018, 172, 1664-1673. [CrossRef]

49. Filho, W.L.; Eustachio, J.H.P.P.; Caldana, A.C.F.; Will, M.; Salvia, A.L.; Rampasso, I.S.; Anholon, R.; Platje, J.; Kovaleva, M. Sustainability leadership in higher education institutions: An overview of challenges. Sustainability 2020, 12, 3761. [CrossRef] 
50. Zen, I.S. Exploring the living learning laboratory: An approach to strengthen campus sustainability initiatives by using sustainability science approach. Int. J. Sustain. High. Educ. 2017, 18, 939-955. [CrossRef]

51. Lozano, R.; Ceulemans, K.; Alonso-Almeida, M.; Huisingh, D.; Lozano, F.J.; Waas, T.; Lambrechts, W.; Lukman, R.; Hugé, J. A review of commitment and implementation of sustainable development in higher education: Results from a worldwide survey. $J$. Clean. Prod. 2015, 108, 1-18. [CrossRef]

52. Hugé, J.; Mac-Lean, C.; Vargas, L. Maturation of sustainability in engineering faculties—From emerging issue to strategy? J. Clean. Prod. 2018, 172, 4277-4285. [CrossRef]

53. Lee, K.-H.; Schaltegger, S. Organizational transformation and higher sustainability management education: The case of the MBA sustainability management. Int. J. Sustain. High. Educ. 2014, 15, 450-472. [CrossRef]

54. Wan Ahmad, W.N.K.; Rezaei, J.; Sadaghiani, S.; Tavasszy, L.A. Evaluation of the external forces affecting the sustainability of oil and gas supply chain using Best Worst Method. J. Clean. Prod. 2017, 153, 242-252. [CrossRef]

55. Putri, N.T.; Amrina, E.; Nurnaeni, S. Students' Perceptions of the Implementation of Sustainable Campus Development Based on Landscape Concepts at Andalas University. Procedia Manuf. 2020, 43, 255-262. [CrossRef]

56. Huang, Y.-M.; Hsieh, M.-Y. An interdisciplinary research on students' employability in technology education to advance higher education enrollment sustainability. Sustainability 2020, 12, 1806. [CrossRef]

57. Marrone, P.; Orsini, F.; Asdrubali, F.; Guattari, C. Environmental performance of universities: Proposal for implementing campus urban morphology as an evaluation parameter in Green Metric. Sustain. Cities Soc. 2018, 42, 226-239. [CrossRef]

58. Villegas-Ch, W.; Palacios-Pacheco, X.; Luján-Mora, S. Application of a smart city model to a traditional university campus with a big data architecture: A sustainable smart campus. Sustainability 2019, 11, 2857. [CrossRef]

59. Arruda Filho, N.P.; Beuter, B.P. Transculturality as a drive for the SDGs achievement. Int. J. Sustain. High. Educ. 2019, $20,822-831$. [CrossRef]

60. Boldureanu, G.; Ionescu, A.M.; Bercu, A.-M.; Bedrule-Grigoruţă, M.V.; Boldureanu, D. Entrepreneurship education through successful entrepreneurial models in higher education institutions. Sustainability 2020, 12, 1267. [CrossRef]

61. Boo, B.; Cha, J. ICT in Context of Student-Driven Project-Based Active Learning; ICT: Mumbai, India, 2011; ISBN 9785901642351.

62. Terziev, V.; Lyubcheva, M.; Georgiev, M. Domestic and International Challenges in Higher Education. 2021. Available online: https:/ / papers.ssrn.com/sol3/papers.cfm?abstract_id=3840258 (accessed on 27 February 2021).

63. Carlson, S. Colleges Get Greener in Operations, but Teaching Sustainability Declines. Chron. High. Educ. 2008, 55 , A24.

64. Mulà, I.; Tilbury, D.; Ryan, A.; Mader, M.; Dlouhá, J.; Mader, C.; Benayas, J.; Dlouhý, J.; Alba, D. Catalysing Change in Higher Education for Sustainable Development: A review of professional development initiatives for university educators. Int. J. Sustain. High. Educ. 2017, 18, 798-820. [CrossRef]

65. Caeiro, S.; Azeiteiro, U.M.; Filho, W.L.; Jabbour, C. Sustainability Assessment Tools in Higher Education Institutions: Mapping Trends and Good Practices Around the World; Springer: Berlin/Heidelberg, Germany, 2013; pp. 1-417.

66. Tight, M. Systematic reviews and meta-analyses of higher education research. Eur. J. High. Educ. 2019, 9, 133-152. [CrossRef]

67. Lukman, R.; Krajnc, D.; Glavic, P. Fostering collaboration between universities regarding regional sustainability initiatives-The University of Maribor. J. Clean. Prod. 2009, 17, 1143-1153. [CrossRef]

68. Díaz Pareja, E.M.; Cámara Estrella, Á.M.; Muñoz Galiano, I.M.; Ortega-Tudela, J.M. Group work: Prospective teachers' acquisition of transversal competences. Educ. Stud. 2018, 44, 45-56. [CrossRef]

69. Ortega-Tudela, J.M.; Cámara-Estrella, Á.M.; Diaz-Pareja, E.M. Aprendizaje-Servicio como estrategia favorecedora del desarrollo de la competencia mediática en futuros docentes. Cult. Educ. 2015, 27, 440-445. [CrossRef]

70. Ferrero-Ferrero, I.; Fernández-Izquierdo, M.Á.; Muñoz-Torres, M.J.; Bellés-Colomer, L. Stakeholder engagement in sustainability reporting in higher education: An analysis of key internal stakeholders' expectations. Int. J. Sustain. High. Educ. 2018, 19, 313-336. [CrossRef]

71. Schmidt, M.T.; Elezi, F.; Lindemann, U. Towards Recursive Plan-Do-Check-Act Cycles for Continuous Improvement. In Proceedings of the 2014 IEEE International Conference on Industrial Engineering and Engineering Managemen, Selangor, Malaysia, 9-12 December 2014; pp. 1486-1490.

72. Asif, M.; Searcy, C.; Zutshi, A.; Fisscher, O.A. An integrated management systems approach to corporate social responsibility. J. Clean. Prod. 2013, 56, 7-17. [CrossRef]

73. Grosseck, G.; Tîru, L.G.; Bran, R.A. Education for sustainable development: Evolution and perspectives: A bibliometric review of research, 1992-2018. Sustainability 2019, 11, 6136. [CrossRef]

74. Cotton, D.R.E.; Alcock, I. Commitment to environmental sustainability in the UK student population. Stud. High. Educ. 2013, 38, 1457-1471. [CrossRef] 